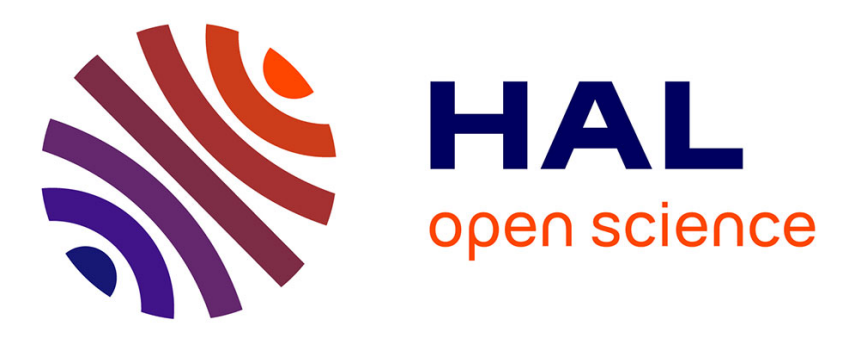

\title{
Implications of carbon forestry for local livelihoods and leakage
}

\author{
George A. Dyer, Maria Nijnik
}

\section{To cite this version:}

George A. Dyer, Maria Nijnik. Implications of carbon forestry for local livelihoods and leakage. Annals of Forest Science, 2014, 71 (2), pp.227 - 237. 10.1007/s13595-013-0293-9 . hal-01098409

\section{HAL Id: hal-01098409 \\ https://hal.science/hal-01098409}

Submitted on 8 Jan 2015

HAL is a multi-disciplinary open access archive for the deposit and dissemination of scientific research documents, whether they are published or not. The documents may come from teaching and research institutions in France or abroad, or from public or private research centers.
L'archive ouverte pluridisciplinaire HAL, est destinée au dépôt et à la diffusion de documents scientifiques de niveau recherche, publiés ou non, émanant des établissements d'enseignement et de recherche français ou étrangers, des laboratoires publics ou privés. 


\title{
Implications of carbon forestry for local livelihoods and leakage
}

\author{
George A. Dyer • Maria Nijnik
}

Received: 13 November 2012 / Accepted: 25 April 2013 /Published online: 30 May 2013

(C) INRA and Springer-Verlag France 2013

\begin{abstract}
- Context An inequitable distribution of the costs and benefits of carbon forestry could undermine its role in tackling climate change, but safeguarding local livelihoods could undercut its effectiveness.

- Aims We simulate a reforestation program in a densely populated locality in central Mexico to analyze indirect land-use change, or leakage, associated with the program and its implications for local livelihoods.

- Methods An agent-based, general equilibrium model simulates scenarios that deconstruct the sources of leakage and livelihood outcomes.

- Results Simulations reveal how conditions linking land, labor, and food markets determine the costs and benefits of reforestation and simultaneously the potential for leakage. Leakage is lowest in remote and poorly integrated localities where declining wages foster local food production while
\end{abstract}

\begin{abstract}
Handling Editor: Erwin Dreyer
Contribution of the co-authors Both co-authors have made substantial contribution to the content: George Dyer developed the model, analysed results, and wrote most of the paper. Maria Nijnik provided the policy framework, contributed to the analysis, and wrote the paper. Both co-authors have approved the paper and agreed to its publication in this journal. Any research in the paper not carried out by the author is fully acknowledged in the manuscript. There are no conflicting interests pertaining to this manuscript.
\end{abstract}

Electronic supplementary material The online version of this article (doi:10.1007/s13595-013-0293-9) contains supplementary material, which is available to authorized users.

G. A. Dyer

Abt Associates, Inc., El Colegio de Mexico, Mexico City, Mexico

\section{Nijnik $(\bowtie)$}

Social, Economic and Geographical Sciences Group, The James

Hutton Institute, Craigiebuckler, Aberdeen,

AB15 8QH, Scotland, UK

e-mail: maria.nijnik@hutton.ac.uk discouraging consumption. Since leakage is tied to consumption, there is a trade-off between the program's effectiveness and an equitable outcome.

- Conclusion An ideal strategy could target those localities with few remaining forests, where a program might lead to agricultural intensification rather than expanding the agricultural frontier. Alternatively, the scheme could incorporate remaining forests to avoid deforestation while encouraging reforestation. An uneven distribution of costs and benefits, where some stakeholders may draw benefits from others' losses, could nevertheless set the stage for conflict. Acknowledging these tradeoffs should help design a politically feasible program that is effective, efficient, and equitable.

Keywords Payments for Ecosystem Services (PES) . Agent-based models · General equilibrium models · Mexico · REDD+

\section{Introduction}

It has been argued recently that social and economic factors could determine the scope of international agreements to tackle climate change through forestry (van Kooten 2012; Nijnik et al. 2012). The international community continues to show interest in carbon forestry projects in developing countries, and the focus is now on implementation mechanisms at the national and sub-national levels (SpringateBaginski and Wollenberg 2010). Whether under the CDM (IPCC 2007), REDD/REDD+ (Angelsen et al. 2009), or REALU initiatives, successful interventions will have to consider their own distributional implications as well as the possibility that they will induce unintended land-use change outside their boundaries, or leakage, undermining their effectiveness (Chomitz 2007; Schwarze et al. 2002; IPCC 2000). The role of carbon forestry could be particularly important in regions where its cost-effectiveness and 
social acceptability are highest (Brown et al. 2004; Nijnik 2010). This could be the case in developing countries where raising the economic value of standing and/or sustainably managed forests can influence land-use decisions. However, the potential gains from forestry projects are rarely seen as a priority in land-use and climate policies in these countries (Nijnik and Halder 2013).

Angelsen et al. (2009) have outlined the challenges of carbon forestry and suggested ways to increase the effectiveness, efficiency, and equity of projects, while other authors have suggested criteria to assess options for a national strategy (Angelsen et al. 2009; Cerbu et al. 2009). Still missing, however, are ways to anticipate their implications and identify their strengths, weaknesses, opportunities, and threats at the local level (Nijnik and Halder 2013). Foremost among these are the implications for livelihoods and leakage.

A variety of forestry interventions have been implemented over the last decade (Springate-Baginski and Wollenberg 2010; Bond et al. 2009; Jagger et al. 2010; Pagiola et al. 2005; Wunder et al. 2008). Simultaneously, there has been an impressive refinement of methods to evaluate public programs, which now include building experimental design into them prior to implementation (Jagger et al. 2010; Ravaillion 2001). Randomized experiments involving "treatment" and "control" groups afford scientists a degree of statistical control over countless unobserved factors that influence program outcomes. The analysis of forest-based initiatives through such methods could provide the basis for scaling up or replicating the most promising schemes (Bond et al. 2009; Jack et al. 2008). Alas, few of them have been subject to critical evaluation (Wunder et al. 2008; Engel et al. 2008; Pagiola et al. 2005; Bond et al. 2009).

Informed policymaking requires additionally that findings be interpreted in light of a "theory of change," i.e., an understanding of the causal mechanisms and multiple factors involved (Jagger et al. 2010; Engel et al. 2008). Controlling the relevant factors nevertheless can be difficult given the diversity of contexts and schemes. Every aspect of project design, including its scale and the type, size, duration, conditionality, and distribution of incentives, exhibits wide variation (Bond et al. 2009; Engel et al. 2008). The diversity of local contexts is even greater. Insufficient baseline information and lack of appropriate "controls" can further hamper systematization efforts. Although matching methods are available to reduce estimation biases (Jagger et al. 2010; Ravaillion 2001), they provide no information on unobserved factors such as the indirect and unintended effects of interventions, which can influence rural livelihoods significantly and constitute a source of leakage (Zilberman et al. 2008; Sierra and Rusman 2006). Importantly, indirect effects of this sort can affect the individuals and communities immediately outside project boundaries that would otherwise constitute ideal matching observations, thus rendering them unsuitable as controls (Sierra and Rusman 2006).

Given the difficulty of measuring economy-wide feedbacks, the indirect effects of interventions have rarely been considered. Also, due to the spatial and temporal nature of pilot studies, statistical analysis can provide limited insight on the effects of large-scale, long-term interventions (Bond et al. 2009; Jack et al. 2008; Pagiola et al. 2005). These limitations can be circumvented to some extent through the use of simulation methods (Dyer et al. 2006, 2012; Kinderman et al. 2008; Busch et al. 2012). Simulation models have been used to analyze international negotiations on reference levels and/or carbon prices (Strassburg et al. 2009; Busch et al. 2012), but the causal chain at the subnational level is extremely simplified in these analyses. Moreover, few models have considered the diversity of actors at the local level and the causal processes of which they are part (Dyer et al. 2012). It is these agents who will be directly responsible for land-use decisions, and their potential gains and losses will determine the acceptability of carbon forestry at this level.

In this paper, we use an agent-based, general equilibrium model of a locality in central Mexico to simulate the implementation of a Payments for Ecosystem Services (PES) program that enhances forest-carbon stocks in a densely populated, heavily deforested developing area. Simulations are used to analyze local market linkages associated with the program. The premise is that these linkages could determine simultaneously local gains and losses and program leakage within and outside its boundaries. Accounting for the market context would be then the first step in designing a program that minimizes leakage without undermining local wellbeing, i.e., a politically feasible program that is also effective, efficient, and equitable. Various simulations analyzing the effect of program design in a particular context were presented in a previous paper (Dyer et al. 2012). Here we present four different simulations designed to highlight the role of the local context.

\section{Methods}

\subsection{Model}

Our methodological framework integrates multiple household models into a single model of a rural locality. The model is based on Zoatecpan, a farming community practicing mixed subsistence/commercial agriculture in central Mexico, and calibrated using survey data for this locality (Table 1) (Dyer et al. 2006, 2012). Online supplementary information describes the model as a set of simultaneous equations. More briefly, each household in the survey 
sample-i.e., 49 households or $10 \%$ of the population-is modeled as an independent decision maker that engages in on- and off-farm activities and interacts with other agents via markets. The system thus consists of the activities of multiple types of agents interacting. The economic context is defined by closure rules that describe markets operating in the locality. When land, labor, and maize markets are strictly local, the locality is defined as a closed system where internal leakage is possible but there is little room for leakage out of the locality. When all markets extend beyond village boundaries, the system is completely open and leakage is almost certain. In an open system, wages, rents, and prices are determined in the greater economy and considered fixed; in a closed system, the demand and supply of each good, factor, and service is satisfied through local adjustments in prices. In all cases, subsistence activities are influenced by their implicit value (or shadow price), which is the sum of the market and non-market value of the goods and services they provide. As described below, in addition to these two extremes, the analysis considers combinations of closure rules in order to identify the role of context in program outcomes and the part played by individual factors in the causal chain.

Among the characteristics defining agents is land ownership, which distinguishes landholders from the landless (Table 1). The average land holding is 0.4 ha, but endowments vary widely, with $2 \%$ of households owning nearly one fifth of the land. Defining activities include the cultivation of staples: $98 \%$ of households grow a multi-crop based on maize. Only $94 \%$ of them own arable land, but landless households also grow crops on rented land. An additional $35 \%$ of landowners rent land to complement their own endowments, creating an alternative classification of agents that distinguishes landlords from tenants. In all, $37 \%$ of arable land passes through the market. Local landlords supply $7 \%$; absentee landowners supply the rest, as they own $30 \%$ of all land in the locality. Agents also can be classified as either employers, including absentee landowners and $48 \%$ of local households, or farm workers (another $48 \%$ ). Similarly, participation in food (i.e., maize) markets distinguishes non-farmers and subsistence farmers $(94 \%$ of households), all of who buy maize, from the commercial (or surplus) producers who sell it. Commercial farmers sell only surpluses, as they consume part of their output on farm. Finally, every agent can be either a participant in carbon forestry or a non-participant.

Simulation results depend critically on the characterization of the land market and the use of land for subsistence activities. Thus, whether Zoatecpan is representative of other rural areas in Mexico (or elsewhere in the developing world) depends on the distribution of land among local households and absentee landowners. Also critical are rules that allocate land to either subsistence or commercial production. In this regard, landholding sizes vary considerably throughout Mexico, with large farms often interspersing with more numerous smallholdings (Dyer and Taylor 2011; Dyer et al. 2012). However, the rental market helps redistribute land among rural farmers in every region, and absentee landowners supply up to $88 \%$ of this land (Dyer and Taylor 2011; Dyer et al. 2012). In Zoatecpan, the figure is $80 \%$, which is representative of that in other localities in central Mexico, $83 \%$. As to the allocation of land, farmers in Zoatecpan respond readily to incentives by renting land in or out (Dyer et al. 2006). Subsistence farmers expand maize production when their income increases but not in response to higher prices, while commercial farmers respond the opposite way (Dyer et al. 2006, 2012). Similarly, across rain-fed areas in Mexico, commercial farmers do not rely on exogenous income to finance maize production (Dyer and Taylor 2011). All of these features are built into the model as stylized facts.

As regards subsistence production, Zoatecpan is outside the norm. Across Mexico, rural farmers consume an estimated $48 \%$ of their maize output (Dyer and Taylor 2011). On-farm consumption is highest in central Mexico, reaching $73 \%$, while the figure in Zoatecpan is $85 \%$ - a reflection of small landholding sizes in the locality, which are also below average. In sum, while not representative of prime agricultural areas in Mexico, our results should apply across the densely populated, highly deforested highlands of central Mexico. More generally, we would expect similar processes

Table 1 Defining characteristics of the study area, Zoatecpan, Mexico

Food production

Food markets

Landowners

Landholdings

Land rental

Labor market
A multi-crop system based on maize is grown by $98 \%$ of local households including landless households that rent land. There is an active market for maize where $96 \%$ of local households buy and $4 \%$ sell. Maize is also "imported" from outside the locality.

Absentee landholders and $94 \%$ of local households own land in the locality.

For local households, the average landholding is 0.4 ha, but $2 \%$ of these landowners own ca. $20 \%$ of local land. Absentee landowners own another $30 \%$.

There is an active land market where $37 \%$ of arable land in the locality is rented; $35 \%$ of local landowners and $4 \%$ of landless households rent land in; local landlords rent out $7 \%$ of all land, absentee landlords rent the remainder.

Absentee landowners and $48 \%$ of local households hire labor; $48 \%$ of local households work as farm hands. 
to those described here wherever subsistence agriculture is widespread, population density high, and landholdings small.

\subsection{Simulations}

We simulate the introduction of a PES program that seeks the regrowth of forest over $10 \%$ of cleared land within its boundaries. Each landowner decides whether to participate in the program and how much land to enroll. In return, the program offers a payment per unit area equal to $110 \%$ of rental rates net of costs; i.e., it covers implementation and transaction costs separately. Since market rates represent the opportunity cost of land, enrollment is an attractive option for everyone-i.e., PES entail a $10 \%$ gain or "economic rent". However, the opportunity cost of land might change as the economy responds to this intervention. For instance, a declining agricultural sector might influence the price of food or farm wages, and thus its own rate of return. On the other hand, program payments could stimulate economic activity if they contribute noticeably to local income, inducing greater consumption. Since these effects can act in different directions (Zilberman et al. 2008), the outcome is an empirical question that depends on local conditions.

In principle, if all markets were open and large, enrollment would influence production decisions directly but would have no indirect effects in the locality. Landowners might use payments to finance their own consumption yet purchase everything they consume in the market. In practice, however, particularly in developing areas, people consume many goods and services that are not sold in markets, including ecosystem services (Smale 2005). Hence, landowners might use program payments to finance production of goods and services on farm. In such case, the program would have an "income effect" on production decisions. Indeed, public transfers often have income effects even in developed countries. Subsistence activities are not immune from this effect because no household is entirely selfsufficient, so its decisions reflect the opportunity cost of family land and labor (Dyer et al. 2006). Income effects thus link production and consumption decisions on farm; however, they can also have repercussions away from the farm. The program's direct effects on production activities might overshadow its income effects, but the latter would be observed in isolation under certain conditions.

We use four different scenarios that assume alternative market conditions to identify the program's various effects on the local economy (Table 2).

In scenario 1, all goods and factor markets are open, their prices fixed and there is full employment, which allows us to identify the income effect on program outcomes. Scenario 2 assumes that labor markets are closed, which allows wages to change, revealing their role. Scenario 3 a assumes a closed land market while keeping wages fixed, thus isolating the implications of rent changes. Wages in this scenario are fixed because there is an open market where households can find full employment (i.e., demand for labor is perfectly elastic). Alternatively, in scenario $3 b$, wages are fixed contractually (e.g., minimum wages) and unemployment becomes a possibility. Finally, scenario 4 explores simultaneous rent and wage changes, which is a more realistic situation. In every scenario, commodity markets, including food, are open. In scenarios 3 and 4, the combination of flexible land rents and a fixed payment implies that economic rents-i.e., the portion of payments in excess of the opportunity cost of land-are variable.

The assumption that wages, rents, and prices are fixed is used generally to imply that the economy is relative small - that is, that land, labor, and agricultural markets extend well beyond the boundaries of the local economy. In the present context, fixed wages, rents, and prices can be interpreted also as a reflection of the program's size. For instance, the assumption of a variable rental rate can imply that the program extends into neighboring localities and therefore has an impact on rents at the regional level. The locality thus becomes representative of other localities within the program's area of coverage. Based on this interpretation, the consequences of expanding the program can be identified by comparing fixed- and flexible-rent scenarios. Similarly, labor-market specifications can be interpreted as an assumption on the duration of the program. In this context, a flexible wage supposes a short-term response where the labor market has not had time to adjust fully. A fixed wage, in contrast, supposes a long-term response where rural out migration has allowed wages to return to normal.

To keep other sources of variation constant, we make a number of simplifying assumptions. We focus on landowners' willingness to participate in PES without considering their eligibility or ability to participate. Simulations assume no eligibility constraints except that local households are given priority over absentee landowners; e.g., smallholders can pool resources to avoid minimum-area requirements or to reduce fixed costs that may otherwise constrain their participation (Grieg-Gran et al. 2005; Pagiola et al. 2005). Extraction of timber or lumber is not allowed, which implies that potential benefits associated with an expanding supply of forest products are not explored. As for the biophysical system, microclimate, soil quality, and other attributes of the land are assumed to be homogenous. Thus, intrinsic agricultural yields as well as total biomass densities are fixed and uniform, which implies that both land rental rates and environmental benefits per unit area also are uniform. Finally, marginal environmental benefits do not change with the scale of implementation, which is reasonable in the case of carbon sequestration. 
Table 2 Simulation scenarios and implications for model variables

\begin{tabular}{|c|c|c|c|c|c|}
\hline & \multicolumn{5}{|c|}{ Scenarios } \\
\hline & 1 & 2 & $3 a$ & $3 b$ & 4 \\
\hline \multicolumn{6}{|l|}{ Market conditions } \\
\hline Land market & \multicolumn{2}{|c|}{ open } & \multicolumn{3}{|c|}{ closed (local) } \\
\hline Labor market & open & closed & open & close & local) \\
\hline Employment & \multicolumn{3}{|c|}{ full employment } & $\begin{array}{l}\text { unemploy- } \\
\text { ment }\end{array}$ & $\begin{array}{c}\text { full } \\
\text { employment }\end{array}$ \\
\hline Food market & \multicolumn{5}{|c|}{ open } \\
\hline \multicolumn{6}{|l|}{ Model variables } \\
\hline Land rents / supply of land & \multicolumn{2}{|c|}{ fixed / unlimited } & \multicolumn{3}{|c|}{ endogenous / fixed } \\
\hline $\begin{array}{l}\text { Wage rates / supply of } \\
\text { labor }\end{array}$ & $\begin{array}{c}\text { fixed / } \\
\text { unlimited }\end{array}$ & $\begin{array}{l}\text { endogneous / } \\
\text { fixed }\end{array}$ & fixe & limited & $\begin{array}{l}\text { endogneous } \\
\text { / fixed }\end{array}$ \\
\hline
\end{tabular}

\subsection{Leakage}

The literature recognizes two types of leakage, also known as displacement. Activity displacement is leakage caused by direct changes in local activities; demand displacement-or market-effects leakage - refers to changes induced vicariously through markets (IPCC 2000; Schwarze et al. 2002). This classification risks confusing the transmission of effects with the mechanisms involved. In our case, for instance, program participants could clear forest areas of their own to replace land enrolled in carbon forestry, or they could rent land from others who may clear land themselves. The participant would engage in land use change in both cases, qualifying as activity displacement, but the second case would also involve a vicarious, market-mediated effect. Moreover, in both cases, land-use change could take place within or outside the program's geographic boundary. The issue's complexity increases because the same market mechanisms may generate leakage or not depending on conditions at the end of the causal chain. We keep the analysis simple by focusing on the mechanisms for leakage, i.e., the market processes through which leakage would operate. Potential leakage is internal or external depending on whether it may occur within or outside the locality.

\section{Results}

In scenario 1, authorities have no difficulty in meeting the program's target in the locality (Table 3).

Every landowner enrolls as much land as possible into PES and, since land markets are open, replaces it by renting land from landowners outside program boundaries. That is, the program does not constrain farming. Payments nevertheless have indirect effects on the local economy. Since landholdings are small and program payments are only $10 \%$ higher than the rental rate (which itself is low due to low productivity), incomes increase only slightly; but given the extent of participation, gains are widespread in the locality (Table 4).

Consumption of both market and non-market goods and services, including maize, increases in turn by $0.4 \%$ on average. Commercial farmers maintain maize output unchanged but sell less, while subsistence farmers are forced to expand production given their lack of surpluses. Since all arable land is either under cultivation or enrolled in PES, they must rent additional land outside the locality to do so. Local maize output increases only by $0.4 \%$, so the village's deficit must be satisfied with maize "imports". This

Table 3 Household participation and land enrollment in simulated PES program

\begin{tabular}{|c|c|c|c|c|c|}
\hline & \multicolumn{5}{|c|}{ Scenarios } \\
\hline & 1 & 2 & $3 a$ & $3 b$ & 4 \\
\hline \multicolumn{6}{|l|}{ Program participation } \\
\hline Participating households ${ }^{\mathrm{a}}$ & 94 & 94 & 35 & 33 & 52 \\
\hline Participants enrolling $>0.5 \mathrm{ha}^{\mathrm{b}}$ & 4 & 4 & 6 & 6 & 4 \\
\hline \multicolumn{6}{|l|}{ Land use } \\
\hline Local enrollment ${ }^{\mathrm{c}}$ & 100 & 100 & 81 & 82 & 97 \\
\hline Agricultural land use $^{\mathrm{d}}$ & $>100$ & $>100$ & 90 & 90 & 90 \\
\hline
\end{tabular}

${ }^{\text {a }}$ As percent of all households in the locality

${ }^{\mathrm{b}}$ As percent of all local participants

c As percent of program's target area

${ }^{\mathrm{d}}$ As percent of original agricultural area 
Table 4 Percentage effects of program implementation on the local economy

\begin{tabular}{|c|c|c|c|c|c|}
\hline \multicolumn{6}{|c|}{ Scenarios } \\
\hline & 1 & 2 & $3 a$ & $3 b$ & 4 \\
\hline \multicolumn{6}{|l|}{ Crops } \\
\hline Total output & 0.4 & 0.1 & -8.6 & -9.1 & -3.2 \\
\hline Subsistence farm output & 0.4 & 0.2 & -0.3 & -1.2 & 0.3 \\
\hline Commercial farm output & 0.0 & 0.0 & -29 & -29 & -12 \\
\hline Local market surplus & -0.1 & -0.7 & -54 & -52 & -22 \\
\hline External purchases & 0.5 & 0.8 & 9.6 & 8.2 & 2.8 \\
\hline Employment & 0.4 & - & -3.7 & -1.8 & - \\
\hline \multicolumn{6}{|l|}{ Value added and rents } \\
\hline Wages & - & 0.9 & - & - & -2.6 \\
\hline Rents & - & - & 3.4 & 2.7 & 7.1 \\
\hline Economic rents & 10 & 10 & 6.4 & 7.1 & 2.7 \\
\hline \multicolumn{6}{|l|}{ Income (nominal) } \\
\hline All households & 0.4 & 0.9 & 0.3 & -0.8 & -0.9 \\
\hline \multicolumn{6}{|l|}{ Income (real) } \\
\hline All households & 0.4 & 0.7 & 0.2 & -0.9 & -0.7 \\
\hline Subsistence farmers & 0.4 & 0.7 & 0.2 & -0.9 & -0.7 \\
\hline Commercial farmers & 0.6 & 1.3 & 0.3 & -1.3 & -1.1 \\
\hline Program participants & 0.5 & 0.8 & 0.4 & -0.7 & -0.7 \\
\hline Non-participants & 0.0 & 0.2 & 0.0 & -1.1 & -0.8 \\
\hline Landlords & 0.5 & 0.8 & 4.1 & 3.6 & 1.7 \\
\hline
\end{tabular}

deficit is the result of greater consumption coupled to the reduction of local surpluses.

Overall, the program has few local repercussions despite wide participation because the locality is completely integrated to the rest of the region. Open markets allow landowners to cultivate more land while employing outside labor. Yet, this has no additional implications in the locality because all value added generated by their response-i.e., rents and wages paid to expand output-leaks out. Households purchase more market goods, but all of these are imported into the village. The regional economy thus absorbs all potential impacts the program could have on local production.

In scenario 2, workers can no longer commute in or out of the locality because the labor market is closed. Therefore, local wages increase by $0.9 \%$ as subsistence production expands, which curtails the employment surge. As a result, subsistence output expands only half as much as in scenario 1. In this case, all wages stay in the locality, so nominal income gains are twice as large as in scenario 1, but real income increases less (after accounting for inflation) (Table 4). Although commodity prices (including maize) remain unchanged in both scenarios, real and nominal incomes in scenario 2 differ because the cost of producing subsistence goods and services rises. That is, the implicit price of non-market goods and services increases.
Comparing scenarios 1 and 2 reveals that the program can have a substantial impact via consumption. When labor markets are closed in scenario 2, nominal income gains due to higher consumption are as large as the direct gains observed in scenario 1. However, a closed labor market also creates scarcity, raising production costs, which reduces the real-term benefits.

Widespread participation in PES precludes large differences in income gains across households, but benefits still vary since they are tied to the ownership of land. In scenario 1 , household gains range from nil for the landless to $3.7 \%$ for some landowners. The range is smaller in scenario 2 , where every household experiences gains of at least $0.3 \%$. Since program transfers represent gains of $0.4 \%$ on average, the program's indirect effects clearly help distribute benefits more evenly across the population.

Scenarios 1 and 2 have no effect on agriculture because land continues to be widely available outside the locality. This is no longer the case in scenario 3a, where the labor market remains open (as in scenario 1) but the land market is closed. In this case, the program's most immediate effect is the scarcity of land. Since program payments are the same as before, landowners are still enticed to participate in PES, but their opportunity costs rise as soon as the program is introduced. Because farmers are unable to rent land outside the locality, enrollment in PES is constrained by their onfarm consumption decisions. In the end, only $35 \%$ of households participate (Table 3). Although subsistence households are among the participants, they enroll substantially less land than in previous scenarios. Overall, local landowners now contribute only $81 \%$ of the target; yet, the program has a much greater impact on the economy than before (Table 4). The scarcity of land results in a $3.4 \%$ increase in land rents and an $8.6 \%$ decrease in agricultural output, which contrasts with the expansion registered in scenarios 1 and 2. Subsistence production declines marginally because households continue to demand non-market goods and services, so the brunt falls on commercial farmers. Their output and sales contract 29 and $54 \%$, respectively, in response to higher production costs.

Employment declines by $3.7 \%$ as a result of the contraction of the agricultural sector, but this has no implications for household income because workers find employment outside the locality. Farmers' income is affected nevertheless by higher rental rates, which also diminish economic rents. Instead of the expected $10 \%$ premium, program payments are now only $6.4 \%$ higher than market rates. Nominal gains differ once again for participants and nonparticipants, and among participants. Average gains for participants are nearly the same as in scenario 1 , but due to the increase in rents, a much larger share of benefits now accrues to landlords. Their income gains increase steeply, from 0.5 to $4.1 \%$. Absentee landowners also benefit from 
greater participation in PES, and due to the weak response of local households, they now contribute one fifth of land enrolled in the program. Given that only $35 \%$ of households participate in the program, average income increases only by $0.2 \%$ in nominal terms, i.e., half as much as in scenario 1. The cost of subsistence production reduces real gains further, and non-participants experience no gains at all.

The program still has an income effect on subsistence activities, but it is indistinguishable from more direct effects on production decisions, which are greater and opposite in sign. Output declines as a result, leading to a $9.6 \%$ increase in open-market purchases, but in contrast to scenario 2 where wage increases magnify the program's effects, constant wages now prevent greater losses.

Scenario $3 b$ represents a slightly different case where the labor market is closed but there is a fixed minimum-wage rate. In this case, the contraction of agriculture leads to $1.8 \%$ unemployment. Average income decreases as a result, curtailing consumption, including demand for non-market goods and services (Table 4). Subsistence output thus contracts $1.2 \%$, in contrast to scenario 3 where it remains largely unaffected. Subsistence responses therefore dampen the increase in land rents observed in scenario 3, limiting the decrease of commercial output and surpluses slightly, and hence also the increase in maize purchases in the open market. The combination of lower rents and income losses has mixed effects on program participation and enrollment: fewer landowners participate, but participants enroll slightly more land than before (Table 3). Unemployment also turns income gains observed in scenario 3 a into $0.8 \%$ losses for the average household. All non-participants and most participants experience real-term losses, while landlords' gains are reduced slightly with respect to scenario $3 \mathrm{a}$.

Scenario 4 combines various features observed in previous scenarios creating a more realistic and complex picture. Setting aside arable land now leads to a decrease in wages (by $2.6 \%$ ) so farmers can afford to hire more workers, limiting the decrease of agricultural output to a third of that observed in scenarios $3 a$ and $b$ (Table 4). Subsistence output changes little despite the substantial increase in rents $(7.1 \%)$. It is commercial farmers again that adjust, but their output and surpluses contract less (12 and $22 \%$, respectively) than in fixed-wage scenarios. Accordingly, food imports increase much less than under fixed wages. Income losses and rent increases curtail demand for arable land. Over half of all households opt for enrolling land in PES, bringing local enrollment close to the target (Table 3 ). Absentee landlords supply only $3 \%$ of the area enrolled.

The repercussions for income also differ markedly from those observed up to this point. Average income decreases more than in any previous scenario $(0.9 \%)$, but losses are distributed more evenly due to the combination of wage and rent changes. A large increase in rental rates raises landowners' income while reducing economic rents to only $2.9 \%$ of market rates, leveling benefits for participants and non-participants. Although there is full employment, a significant drop in wages results in income losses greater than those associated with unemployment in scenario $3 \mathrm{~b}$. The result is detrimental for workers but favorable for employers. Only $12 \%$ of households experience real income gains; the average participant experiences a $0.7 \%$ real loss, while local landlords' gains are $1.7 \%$.

\section{Discussion}

A crucial question for authorities is where to promote carbon forestry. From an efficiency perspective, an obvious consideration is the quality of environmental services available. Places where the total biomass density of natural ecosystems is above average, such as the cloud forests in the study area, are a prime target (Cairns et al. 2000). A project's cost efficiency may also depend decisively on social factors. Subsistence consumption, for instance, could raise the local price of carbon as large-scale interventions unfurl (Dyer et al. 2012). But equally important are carbon forestry's implications for local livelihoods and the potential for leakage, that is, its effectiveness and equitability.

Careful choice of project characteristics such as the proportion of land targeted for reforestation in a locality or the price paid to participating landowners can improve the efficiency and equitability of interventions (Dyer et al. 2012). As we argue here, deliberate choice of location based on the market context is a critical determinant of their effectiveness. Also important is that the context's influence on the effectiveness and equitability of carbon forestry cannot be considered separately since both livelihood impacts and leakage arise from the same processes.

At the core of this issue are market-mediated responses to land-use change (Hertel et al. 2010); and although land markets are central, they are not the only route for the transmission of indirect and unintended effects (Angelsen 2007). Carbon forestry could affect local wellbeing or induce land-use pressure indirectly through multiple markets simultaneously, including food, land, and labor markets. Shifts in any of these markets are a potential source of leakage and/or livelihood effects. Yet, it is the combination of multiple market linkages that determines the scale and location of these effects. We discuss the implications for livelihoods and leakage separately in the following sections and then consider them jointly in the conclusion.

\subsection{Costs and benefits}

It is well known that the size and quality of landholdings can shape the distribution of gains and losses in PES programs 
(Pagiola et al. 2005; Jack et al. 2008; Zilberman et al. 2008). Although seldom recognized, the market context can play an equally important role. For instance, in our model economy, a moderate-sized program could entail gains for large landowners while, in certain contexts, creating losses for the average household and many participants. We can understand the context's implications for equitability clearly by comparing different scenarios while deconstructing the ensuing gains and losses into their respective market and nonmarket sources. The comparison will also allow us to assess which localities may benefit or lose most from carbon forestry.

The program's direct contribution to local income consists of payments to participating landowners (scenario 1). These payments may induce land-use change within and outside the program but will have no additional repercussions on local incomes if the locality is well integrated to the regional economy. That is, no additional benefits or costs will arise locally unless wages, rental rates, or crop prices change. If wages increase, they will add to the program's nominal benefits but also entail costs that reduce these benefits in real terms (compare scenarios 1 and 2). Costs and benefits will not be distributed evenly. Program participants will appropriate the program's economic rents fully without assuming its indirect costs as long as they are able to rent other people's land at the original market rate (scenario 2). Clearly, their ability to arbitrage diminishes when land markets are closed and rental rates rise (scenario $3 \mathrm{a}$ ). If wages remain unchanged, rental rates will increase moderately with the program, creating a different set of costs and benefits for various groups (compare scenarios 1 and 3 ). Rental rates will increase landlords' income while decreasing that of tenants, none of who participate in carbon forestry. Although higher rates also reduce the economic rents obtained by participating landowners, splitting the returns to land into market rents and economic rents is of no consequence to their net income if arbitrage is not possible; participants continue receiving full payment. The implication is that the program's costs will not be borne by participants entirely but mostly by farmers that do not participate in PES, while landlords benefit at their expense. Consumers of non-market goods and services also will pay a price, as higher land rents raise the cost of production (compare scenarios 1 and 3 ).

Additional costs can occur in a locality where both land and labor markets are closed. A closed labor market has positive implications when the supply of land is not limiting (scenario 2). In that case, wages increase as food production expands, multiplying the program's benefits. The situation is the exact opposite when land markets are closed and land becomes scarce after the program is implemented, increasing land rents and simultaneously creating unemployment (scenario $3 b$ ) or depressing wages (scenario 4). In this case, lower wages and unemployment multiply program costsi.e., the costs of setting arable land aside for reforestation (compare scenarios $3 b$ and 4 with 2). In the process, income is redistributed in favor of landlords and employers at the expense of tenants and farm workers. Other implications differ depending on whether wages fall or there is unemployment. Falling wages ameliorate the impact on agriculture, curtailing real-income losses for farmers employing hired labor, while minimum wages create unemployment but constrain nominal losses for the average worker, spreading the costs to farmers (compare scenarios $3 b$ and 4). In a fixed-wage economy, the implicit price of non-market goods and services increases as agriculture contracts, reducing their affordability; the opposite is true when wages fall.

Although these costs are relatively small, given the range of actors affected they could jeopardize carbon forestry's acceptability as it expands beyond the scope of pilot projects, influencing regional markets for land and labor. We have not explored the potential gains associated with an expanding supply of forest products, which could increase the benefits to local stakeholders. However, these may not compensate the loss of non-market goods and services provided by agriculture. Alternatively, employment opportunities could be created by hiring labor to aid reforestation (Pagiola et al. 2005); but this entails wage costs that must be borne by either program participants or administrators (Dyer et al. 2012). Absent a mechanism to mitigate losses, surplus labor may eventually migrate out of rural areas, allowing wages and employment to return to normal, creating a more favorable balance of costs and benefits for those that stay behind.

\subsection{Leakage}

Indirect land-use change can influence the effectiveness of emissions-reduction strategies decisively (Hertel et al. 2010). Averting this leakage is thus one of carbon forestry's most important challenges (Nijnik and Halder 2013). Our analysis shows that the potential for leakage could vary across localities as a function of the same context variables that determine a project's social implications. If a locality is well integrated with the rest of the region, land-use pressure induced unintentionally through the program will dissipate over a wide area without visible effects on rents, wages, or crop prices (scenario 1). This does not preclude leakage. Although possibly negligible at the scale of the whole region, land-use change could still be significant relative to the program's size. In our model economy, for instance, land rental outside the locality exceeds the area reforested within the program. And although demand for external labor in principle reduces the pressure on forests simultaneously, food imports have the opposite effect. Overall, rather than decreasing land-use pressure at the regional scale, the 
program increases it with potentially counterproductive results (scenario 1).

When the labor market is closed (scenario 2), the program does not draw workers in but instead raises local wages slightly, increasing incomes and consumption. That is, the potential for negative leakage through the labor market ceases while positive leakage through the food market increases. Total external leakage is thus higher. Moreover, high wages do not decrease the pressure on local forests because the land market remains open (scenario 2). As long as farmers can rent land across program boundaries, all indirect effects continue to leak through this route, offsetting local reforestation efforts. When this route alone is closed (scenarios $3 \mathrm{a}$ and $3 \mathrm{~b}$ ), the scarcity of land and rising rents turn land-use pressure inward onto local forests, but this does not preclude external leakage through other routes. Although its effect may be much smaller, the program still exerts land-use pressure vicariously via food and/or labor markets. The potential for external leakage through each route depends on whether the other is open too, and it is potentially highest when both are open (scenario $3 \mathrm{a}$ ): since food production cannot expand despite increasing demand, the community resorts to importing food; and the potential for leakage increases further as workers turn outside for employment (compare scenarios 1 and 3a). On the other hand, if commuting is not possible and unemployment increases, income and hence consumption decline, reducing local land-use pressure and food imports simultaneously (compare scenarios $3 \mathrm{a}$ and $3 \mathrm{~b}$ ). That is, the potential for leakage within and outside the locality is slightly lower when the wage is fixed contractually rather than by the market.

More generally, external leakage is highest when local wages cannot adjust. The reason is that otherwise declining wages will foster local food production while discouraging consumption, so nominal income and expenditure are lower than under unemployment (compare scenarios $3 \mathrm{~b}$ and 4). That is, when wages fall, increasing surpluses help reduce food imports as much as decreasing demand does. Although internal leakage is potentially higher, total leakage is considerably lower. This is clear because the increase in local rents subsumes all direct and indirect land-use effects via land and labor markets.

\section{Conclusions}

Carbon sequestration could increase the value of forests in remote developing areas where transportation costs limit the feasibility of conventional forestry. The same costs also prevent the integration of land and labor in these areas into the greater economy. In such circumstances, where land and labor markets cannot be considered entirely open, carbon forestry will likely result in changes in local rents and wages. A realistic scenario could see wages adjusting downwards, which would encourage subsistence agriculture or food production in general. This may increase land-use pressure locally but decrease the potential for external leakage through food markets even more, reducing potential leakage at the regional scale to a minimum. As observed above, this trade-off between internal and external leakage is absent when farmers can rent land across program boundaries since all indirect effects escape through this route. This suggests that if internal leakage can be prevented, targeting remote, poorly integrated localities could be the most effective way to increase carbon stocks at a regional scale.

An ideal strategy could be to target localities with few remaining forests, so that setting aside arable land might lead to agricultural intensification rather than the expansion of the agricultural frontier. Alternatively, internal leakage could be averted by incorporating remaining forests into PES, i.e., by avoiding deforestation while encouraging reforestation. Efficiency and effectiveness are not free of cost, nevertheless, and the implications for local wellbeing need to be considered. Significantly, our analysis reveals that the potential for leakage is smallest in poorly integrated localities because consumption falls the most there as a result of income losses. In contrast, a program that generates income gains for local households may be completely ineffective because external leakage can offset local reforestation entirely. Overall, if minimizing leakage depends on reducing consumption, authorities must take into account the tradeoff between effectiveness and equitability. Also important is that the gains and losses of carbon forestry will not be distributed evenly. In fact, some stakeholders may draw benefits from others' losses, which could set the stage for conflict. Alternative ways of addressing the potential implications for local livelihoods can have repercussions of their own (Dyer et al. 2012). A program that prevents job losses could be the best option, but its efficiency compared to direct compensation could depend on program scale (Dyer et al. 2012).

In light of these issues, carbon-forestry programs should develop alongside with institutions to safeguard local rights, including food security and the right to work, as well as along with the adaptability of national legal and economic interests (Angelsen et al. 2012; Zomer et al. 2008). When rights to land are not secure, there is a risk that carbon forestry could result in the expropriation or "green grabbing” of this resource (Fairhead et al. 2012).

Designing carbon-forestry initiatives that are both effective and equitable remains a challenge. Statutory restrictions on forestry projects under the Clean Development Mechanism limited their ability to reduce green-house-gas emissions while promoting sustainable development in host countries (Brown et al. 2004). The capabilities needed to 
negotiate, manage, and support projects have evolved rapidly under the umbrella of REDD+, yet numerous challenges remain. International support for REDD + is based on its promise as a strategy to reduce green-house-gas emissions and mitigate climate change. However, it is crucial that projects also bring benefits to local communities and their environment. Our findings contribute new arguments to insights offered by authors who have stressed the need to safeguard the rights and wellbeing of local communities while seeking to ensure the effectiveness of interventions (Angelsen et al. 2012).

Acknowledgments and funding This research falls under the FP7 "Reducing Emissions from Deforestation and Degradation through Alternative Land Uses in Rainforests of the Tropics" project (REDDALERT) and the COST Action FP0703 "Expected Climate Change and Options for European Silviculture". Financial support was provided by the European Commission, Grant Agreement 226310. We are also grateful for the support provided by the Scottish Government under the RESAS Programme, and to J. Edward Taylor, Deborah Roberts, and to reviewers for their helpful comments on an earlier draft.

\section{References}

Angelsen A (2007) Forest cover change in space and time: combining the von Thunen and forest transition theories. World Bank Policy Res. Work. Pap. 4117

Angelsen A, Brockhaus M, Kanninen M, Sills E, Sunderlin WD, Wertz-Kanounnikoff S (eds) (2009) Realising REDD+. National strategy and policy options. Centre for International and Forestry Research (CIFOR), Bogor, Indonesia, 320p

Angelsen A, Brockhaus M, Sunderlin WD, Verchot LV (2012) Analysing REDD+: challenges and choices. CIFOR, Bogor, Indonesia

Bond I M, Grieg-Gran S, Wertz-Kanounnikoff P, Hazlewood P, Wunder S, Angelsen A (2009) Incentives to sustain forest ecosystem services: a review and lessons for REDD. Nat. Resour. Issues No 16. International Institute for Environment and Development, London UK, with CIFOR, Bogor, Indonesia, and World Resources Institute, Washington DC

Brown K, Adger W.N, Boyd E, Elizalde EC, Shackley S (2004) How do CDM projects contribute to sustainable development? Tech. Rep. 16. Tyndall Centre, Norwich, $54 \mathrm{p}$

Busch J, Lubowski RN, Godoy F, Steininger M, Yusuf AA (2012) Structuring economic incentives to reduce emissions from deforestation within Indonesia. Proc Natl Acad Sci USA 109:1062-1067

Cairns M, Haggerty PK, Alvarez R, de Jong BHJ, Olmsted I (2000) Tropical Mexico's recent land-use change: a region's contribution to the global carbon cycle. Ecol Apl 10:1426-1441

Cerbu G, Minang P, Swallow B, Meady V (2009) Global Survey of REDD Projects: What Implications for Global Climate Objectives? ASB Policy Brief No 12 . ASB Partnership for the Tropical Forest Margins, Nairobi, Kenya

Chomitz KM (2007) At loggerheads: agricultural expansion, poverty reduction, and environment in the tropical forests. The World Bank, Washington D.C., $284 \mathrm{pp}$

Dyer G, Taylor JE (2011) The corn price surge: impacts in rural Mexico. World Dev 39:1878-1887

Dyer G, Taylor JE, Boucher S (2006) Subsistence response to market shocks. Am J Agric Econ 88:279-291
Dyer G, Matthews R, Meyfroydt P (2012) Is there an ideal REDD+ program? An analysis of policy trade-offs. PLoS One 7:e52478. doi:10.1371/journal.pone.0052478

Engel S, Pagiola S, Wunder S (2008) Designing payments for environmental services in theory and practice: an overview of the issues. Ecol Econ 65:663-674

Fairhead J, Leach M, Scoones I (2012) Green grabbing: a new appropriation of nature? J Peasant Stud 39:237-261

Grieg-Gran M, Porras I, Wunder S (2005) How can market mechanisms for forest environmental services help the poor? Preliminary lessons from Latin America. World Dev 33:1511-1527

Hertel TW, Golub AA, Jones AD, O'Hare M, Plevin RJ, Kammen DM (2010) Effects of US maize ethanol on global land use and greenhouse gas emissions: estimating market-mediated responses. Biosci 60:223-231

IPCC (2000) Land-use change and forestry. In: Watson RT, Noble IR, Bolin B, Ravindranath HH, Verado DJ, Dokken DJ (eds) Land use. Intergovernmental Panel on Climate Change, Geneva, Ch. 5

IPCC (2007) Climate Change 2007: Synthesis Report. Contribution of Working Groups I, II and III to the Fourth Assessment Report of the Intergovernmental Panel on Climate Change IPCC, Geneva, $104 \mathrm{p}$

Jack BK, Kousky C, Sims KRE (2008) Designing payments for ecosystem services: lessons from previous experience with incentive-based mechanisms. Proc Natl Acad USA 105:9465-9470

Jagger P, Sills EO, Lawlor K, Sunderlin WD (2010) A guide to learning about livelihood impact of REDD+ projects. Occas. Pap. 56, CIFOR Bogor, Indonesia

Kinderman G, Obersteiner M, Sohngen B, Sathatye J, Andrasko K, Rametsteiner E, Schlamadinger B, Wunder S, Beach R (2008) Global cost estimates of reducing carbon emissions through avoided deforestation. Proc Natl Acad USA 105:10302-10307

Nijnik M (2010) Carbon capture and storage in forests. The Royal Society of Chemistry, Cambridge. In: Hester RE, Harrison RM (eds) Carbon capture: sequestration and storage, vol 29, Issues in Environmental Science and Technology., pp 203-238

Nijnik M, Halder P (2013) Afforestation and reforestation projects in South and South-East Asia under the CDM: trends and development opportunities. Land Use Policy 31:504-515. doi:10.1016/ j.landusepol. 2012.08.014

Nijnik M, Oskam A, Nijnik A (2012) Afforestation for the provision of multiple ecosystem services. Int J For Res. doi:10.1155/2012/ 295414

Pagiola S, Arcenas A, Platais G (2005) Can payments for environmental services help reduce poverty? An exploration of the issues and the evidence to date from Latin America. World Dev 33:237-253

Ravaillion M (2001) The mystery of the vanishing benefits: an introduction to impact evaluation. The World Bank Econ Rev 15:115-140

Schwarze R, Niles JO, Olander J (2002) Understanding and managing leakage in forest-based GHG-mitigation projects. Phil Trans Math Phys Eng Sci 360:1685-1703

Sierra R, Rusman E (2006) On the efficiency of environmental service payments: a forest conservation assessment in the Osa Peninsula, Costa Rica. Ecol Econ 59:131-141

Smale M (ed) (2005) Valuing crop biodiversity: on-farm genetic resources and economic change. International Plant Genetic Resources Institute (IPGRI). CABI, Wallingford

Springate-Baginski O, Wollenberg E (eds) (2010) REDD, forest governance and rural livelihoods: the emerging agenda. CIFOR, Bogor, Indonesia

Strassburg B, Turner K, Fisher B, Schaeffer R, Lovett A (2009) Reducing emissions from deforestation: the 'combined incentives' mechanism and empirical simulations. Glob Environ Chang 19:265-278 
Van Kooten GC (2012) Climate change, climate science and economics: prospects for a renewable energy future. Springer, Dordrecht

Wunder S, Engel S, Pagiola S (2008) Taking stock: a comparative analysis of payments for environmental services programs in developed and developing countries. Ecol Econ $65: 834-852$
Zilberman D, Lipper L, McCarthy N (2008) When could payments for environmental services benefit the poor? Environ Dev Econ 13:255-278

Zomer RJ, Trabucco A, Bossio DA, van Straaten O, Verchot LV (2008) Climate change mitigation: a spatial analysis of global land suitability for clean development mechanism afforestation and reforestation. Agric Ecosyst Environ 126:67-80 